\title{
Predation in nature by a scorpion-hunter, Stenorrhina freminvillei (Serpentes, Colubridae)
}

\author{
Alejandro Solórzano ${ }^{1,2}$ and Harry W. Greene ${ }^{3,4}$ \\ ${ }^{1}$ Museo de Zoología, Universidad de Costa Rica, Ciudad Universitaria Rodrigo Facio, San Pedro de Montes de Oca, San José, Costa Rica. E-mail: \\ solorzano29@gmail.com \\ ${ }^{2}$ Serpentario Nacional de Costa Rica, INBioparque, Santo Domingo, Heredia \\ ${ }^{3}$ Department of Ecology and Evolutionary Biology, Cornell University, Ithaca, New York 14853, U.S.A. E-mail: hwg5@cornell.edu \\ ${ }^{4}$ Author for correspondence
}

Recibido 17-X-2011 Corregido 03-XI-2011 Aceptado 14-XI-2011

\section{ABSTRACT}

Sonorini snakes are arthropod specialists but we know of only one published diet record for Stenorrhina freminvillei. Here we present quantitative data for predation on scorpions in nature by S. freminvillei: in nature, it consumes among other prey, relatively small scorpions, head-first.

\section{KEY WORDS}

Serpentes, Stenorrhina, scorpion, Centruroides, predation, venom.

\section{RESUMEN}

Los contenidos estomacales confirman que, en la naturaleza, Stenorrhina freminvillei consume escorpiones relativamente pequeños, iniciando por la parte cefálica.

\section{PALABRAS CLAVE}

Serpentes, Stenorrhina, escorpión, Centruroides, depredación, veneno.
Snakes of the colubrid clade Sonorini are arthropod specialists (Greene 1997) and among them the two species of Stenorrhina are widely reported to eat insects, spiders, and scorpions (Alvarez del Toro 1972, Lee 1996, Savage 2002, Köhler 2003). Nevertheless, despite their Spanish and English names ("alacranera"-scorpion-hunter or scorpion eater), we know of only three published diet records for S. degenhardtii (a large spider, Duellman 1963; a spider and an orthopteran, Sexton and Heatwole 1965) and only one for S. freminvillei (an individual in Mexico with tarantula in its stomach that was found ingesting a scorpion from the posterior abdomen [mesosoma], Luja 2007). Here we present quantitative data for predation on scorpions in nature by S. freminvillei.

An adult female (MZUCR-19140 in the Museo de Zoología, Universidad de Costa Rica) was captured at approximately 2300 hrs, July 12, 2006, crossing a road in Quebrada Grande de Liberia, approximately $3 \mathrm{~km}$ outside the entrance to Santa Rosa National Park, Guanacaste Province, Costa Rica. After preservation and subsequent removal of prey items she had a snout-vent length of $449 \mathrm{~mm}$, tail length of $75 \mathrm{~mm}$, and mass of $52,67 \mathrm{~g}$. Her stomach contained two reasonably intact Common Black Scorpions (Centruroides margaritatus) that had been swallowed "head-first" (i.e., beginning with the cephalothorax or prosoma, Figure 1); the more posterior and smaller prey item was a female with a total length of $75 \mathrm{~mm}$ and mass of $1,38 \mathrm{~g}$ (prey/predator mass ratio [MR] 0,026), while the more anterior and larger item was a male with a total length of $113 \mathrm{~mm}$ and mass of 2,93 g (MR 0,056). Among live conspecific scorpions held captive at the Instituto Clodomiro Picado, two large males weighed 2,89 and 2,90 g, and two smaller females weighed 1,41 and 2,05 g.

Alvarez del Toro (1972) reported that captive S. freminvillei usually grasped a scorpion's anterior end and the snake's overlapping scales formed an effective armor 


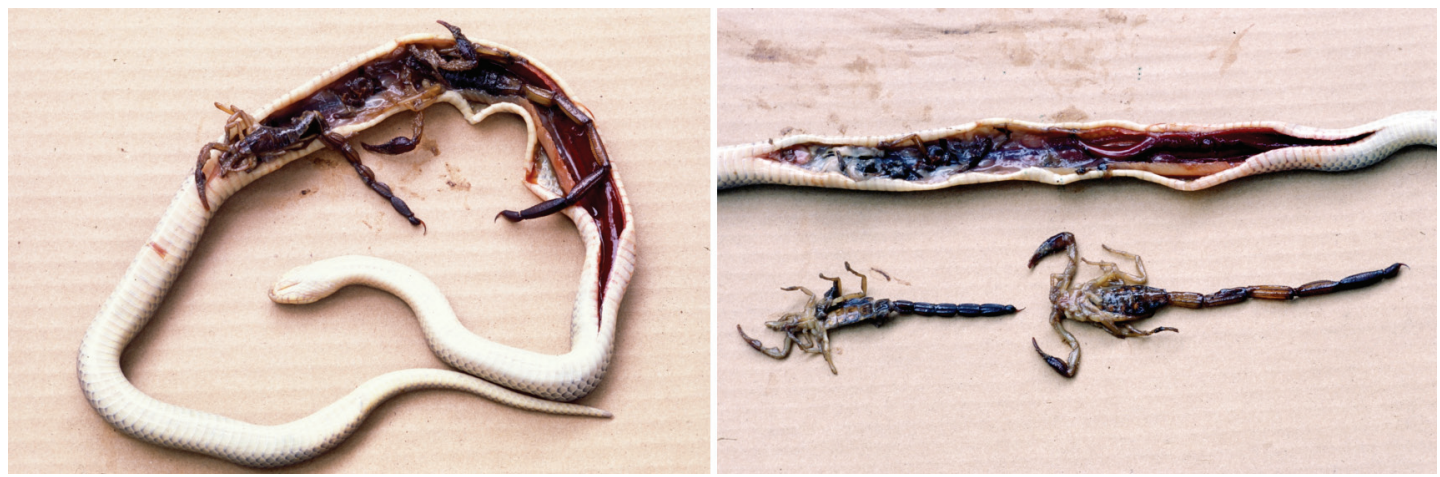

FIG. 1. Ventral views of Stenorrhina freminvillei with two scorpions in stomach (left) and removed (right).

against the arachnid's sting, scorpions were swallowed head-first with the chelae folded back, and the snakes seemed immune to scorpion stings. He also noted that a small captive was seemingly affected by the sting of a large scorpion, momentarily released its prey, and later subdued and swallowed it with difficulty. Solórzano (2004) saw a captive $S$. freminvillei seize a $C$. margaritatus by the abdomen (mesosoma), then use a loop of the snake's body to immobilize the tail (metasoma) and venomous telson. Our findings confirm that adult S. freminvillei also consume scorpions head-first in nature, and demonstrate that two diet items were small (MR ca. 2-5\%) compared to non-venomous prey taken by many other colubrids (reviewed by Rodríguez-Robles 2002). Prey mass and defensive capability might thus favor behavioral versatility in subduing scorpions as well as restrict predation by S. freminvillei to relatively small items, and clearly these interactions are worthy of more detailed studies.

\section{ACKNOWLEDGMENTS}

We thank Carolina Vega for weighing the preserved and live scorpions.

\section{REFERENCES}

Alvarez del Toro, M. 1972. Los Reptiles de Chiapas. Gobierno del Estado de Chiapas, Tuxtla Gutiérrez, Mexico.

Duellman, W. E. 1963. Amphibians and Reptiles of the rainforests of southern El Petén, Guatemala. Univ. Kansas Publ., Mus. Nat. Hist., 15:205-249.

Greene, H. W. 1997. Snakes: the evolution of mystery in nature. University of California Press, Berkeley, U.S. A.

Köhler, K. 2003. Reptiles of Central America. Herpeton, Verlag Elke Köhler. Offenbach, Germany.

Lee, J. C. 1996. The amphibians and reptiles of the Yucatán Peninsula. Cornell University Press, Ithaca, NY, U. S. A.

Luja, V. H. 2007. Stenorrhina fremninvillei (Fremenville's Scorpioneating Snake). Diet. Herpetological Review 38: 211.

Rodríguez-Robles, J. A. 2002. Feeding ecology of North American gopher snakes (Pituophis catenifer, Colubridae). Biological Journal of Linnean Society 77:165-183.

Savage, J. M. 2002. The amphibians and reptiles of Costa Rica: a herpetofauna between two continents, between two seas. University of Chicago Press, Chicago, U. S. A.

Sexton, O. J., and H. A. Heatwole. 1965. Life history notes on some Panamanian snakes. Caribbean Journal of Science 5:39-43.

Solórzano, A. 2004. Serpientes de Costa Rica: Distribución, taxonomía e historia natural. Instituto Nacional de Biodiversidad. Santo Domingo de Heredia, Costa Rica. 